\section{Hague University of Applied Sciences}

\author{
Johanna Westerdijkplein 75, NL-2521 EN Den Haag, \\ Netherlands.
}

Tel:

(31) 704458888

Website: www.thehagueuniversity.com/

Let's change. You. Us. The world. That's our message at The Hague University of Applied Sciences (THUAS). We want to empower our students to change and improve the world they live in, but this can only happen if we work together - if we evolve and change. We constantly need to apply new perspectives and solutions to resolve present and future challenges. We'll find the answers more quickly if we're prepared to share and apply each other's insights, skills and methods.

\section{Susana Menendez Bright Future Scholarship}

Purpose: We proudly present our 'Bright Future Scholarship', a full scholarship opportunity for Dutch asylum status holders

Level of Study: Masters Degree

Value: full tuition fee

Country of Study: Any country

Application Procedure: Step 1. Apply for the Master's programme of your choice using the online application tool. Step 2. Write an essay (in English, 900 to 1100 words) outlining in what ways you intend to be an impactful innovator. What would you like to contribute to creating a better world with your degree? Please read our essay guidelines and further information on the assessment procedure below before you start writing. Step 3. Submit your essay by emailing it to masters-admission@hhs.nl. Please write 'BFS' in the subject line and state your student number in the essay. Step 4. If you

(C) Springer Nature Limited 2021

Palgrave Macmillan (ed.), The Grants Register 2022,

https://doi.org/10.1057/978-1-349-96042-2 are required to take a PPS-V test, we will provide you with more information.

Closing Date: 15 May

\section{For further information contact:}

Tel: $\quad$ (31) 704458900

Email: masters-admission@hhs.nl

\section{World Citizen Talent Scholarship for International Students}

Purpose: Each year, a maximum of three (one-time) scholarships each worth $€ 5,000$ are available to prospective master's degree students. The University is seeking young, intelligent, talented and ambitious people who view themselves as citizens of the world.

Eligibility: You are eligible for a World Citizen Talent Scholarship if you 1. Come from outside The Netherlands and don't live in the Netherlands. 2. Are enrolling for the first time at The Hague University of Applied Sciences. 3. Have never applied for this scholarship before. 4. Have been conditionally accepted as a student (also-called offer of student position) on or before 31 March for the upcoming academic year.

Level of Study: Masters Degree

Type: Scholarships

Value: $€ 5,000$.

Frequency: Annual

Country of Study: Netherlands

Application Procedure: To apply for the scholarship, you must first apply to the Master programme of your choice and write an essay following the essay guidelines. Submit your essay by completing the scholarship application form between 1 November-31 March. It is important to visit the official website to access the application form and for detailed information on how to apply for this scholarship.

No. of awards offered: 3

Closing Date: 31 March 
Additional Information: www.thehagueuniversity.com/studychoice/masters-professional-courses/scholarships/world-citizentalent-scholarship

For further information contact:

Email: masters-admission@hhs.nl

\section{Harish-Chandra Research Institute}

Chhatnag Road, Jhusi, Allahabad, Uttar Pradesh 211019, India.

Tel: $\quad$ (91) 5322569509

Contact: The Harish-Chandra Research Institute

The Institute started in 1975, on an endowment from the B.S. Mehta Trust, Calcutta. Indeed, until October, 2001, the Institute was named the Mehta Research Institute.

\section{Postdoctoral Fellowships in Mathematics at Harish-Chandra Research Institute}

Purpose: The Harish-Chandra Research Institute (HRI) welcomes applications to its active post-doctoral programme in mathematics. Post-doctoral fellows at HRI have the opportunity to work with the members of the mathematics group in diverse areas including Number Theory, Cryptography, Group Theory, Representation Theory, Harmonic Analysis, Algebraic Geometry and Differential Geometry.

Eligibility: Covering letter, Curriculum Vitae, List of publications, A list of referees, A research plan for the next two years, $\mathrm{PhD}$ degree / Provisional certificate, if available, Document showing prior PDF experience, if any.

Type: Postdoctoral fellowship

Length of Study: Three years

Closing Date: 31 December

Additional Information: www.hri.res.in/academics/mathe matics/pdf-fellowships/

For further information contact:

Email: physvisit@hri.res.in

\section{Postdoctoral Fellowships in Physics at Harish- Chandra Research Institute}

Purpose: The aim of the fellowships is to support Indian students and provide opportunities to researchers working in
Astrophysics, Condensed Matter Physics, High Energy Phenomenology, Quantum Information \& Computing, and String Theory

Eligibility: Applicants from India are eligible to apply for the fellowship. Applicants must be researchers

Type: Postdoctoral fellowship

Value: HRI offers opportunities to researchers working in Astrophysics, Condensed matter physics, High energy phenomenology, Quantum information \& computing, and, String theory

Study Establishment: Fellowships are awarded in the field of Physics

Country of Study: India

Application Procedure: See the website

Closing Date: 31 December

Additional Information: For more details please visit the website at scholarship-positions.com/postdoctoral-fellowshipsphysics-harish-chandra-research-institute-india/2017/12/26/ www.hri.res.in/academics/physics/pdf-fellowships/

For further information contact:

Email: physvisit@hri.res.in

\section{Harpo Foundation}

Tel: $\quad$ (1) 7577354269

Website: www.harpofoundation.org/

The Harpo Foundation was established in 2006 by artist Ed Levine to support emerging and under recognized visual artists. Through grants and residency programs, the foundation seeks to stimulate creative inquiry and encourage new modes of making and thinking about art.

\section{Harpo Foundation Grants for Visual Artists}

Subjects: Visual Arts

Purpose: The award provides direct support to underrecognized artists

Eligibility: 1. Self-defined under-recognized visual artist 21 years or older 2. United States citizen 3. Students who are enrolled in an undergraduate/graduate program are not eligible. 4. Not a previous recipient of a direct artist grant from Harpo. 5. Artists who have been supported by an organizational grant from Harpo in the past are eligible to apply for a direct grant.

Level of Study: Professional development

Type: Grant 
Value: Up to US $\$ 10,000$

Length of Study: 10-months

Frequency: Annual

Country of Study: United States of America

Application Procedure: To apply, a US\$15 application fee is required. Fees are applied to grant administration and program development. Applicants must use the foundation's online application system to submit the following: 1. Artist resume 2. Artist statement (up to 200 words) 3. Work samples (up to 10)

Closing Date: 30 April

Funding: Foundation

Additional Information: www.harpofoundation.org/apply/ grants-for-visual-artists/

\section{For further information contact:}

Email: jdeamer@harpofoundation.org

\section{Harry S Truman Library Institute}

5151 Troost Ave., Suite 300, Kansas City, MO 64110, United States of America.

Tel: $\quad$ (1) 8164001212

Email: truman.reference@nara.gov

Website: www.trumanlibrary.org

The Harry S Truman Library Institute is a non-profit partner of the Harry S Truman Library. The institute's purpose is to foster the Truman Library as a centre for research and as a provider of educational and public programmes.

\section{Harry S Truman Library Institute Dissertation Year Fellowships}

Purpose: Dissertation Year Fellowships are intended to encourage historical scholarship of the public career of Harry S. Truman or the Truman era.

Eligibility: 1. Must be a graduate student 2. Must attend a university 3 . Must not be attending high school currently 4. Must study full-time

Level of Study: Graduate, Postgraduate

Type: Fellowship

Value: US $\$ 16,000$

Length of Study: 1 year

Frequency: Annual

Country of Study: United States of America
Application Procedure: Application forms are available from the website

Closing Date: 1 February

Funding: Private

No. of awards given last year: 2

Additional Information: Recipients will not be required to come to the Truman Library but will be expected to furnish the Library with a copy of their dissertation www. trumanlibraryinstitute.org/research-grants/dissertation-yearfellowships/

\section{For further information contact:}

Truman Library Institute, 5151 Troost Avenue, Suite 300, Kansas City, MO 64110, United States of America.

Tel: $\quad$ (1) 8164001216

Fax: (1) 8162688299

Email: Lisa.Sullivan@TrumanLibraryInstitute.org

\section{Harry S Truman Library Institute Research Grant}

Purpose: As part of our mission, Truman Library Institute grants are given for the purpose of supporting scholarship based on some aspect of the life and career of Harry $\mathrm{S}$. Truman or of the public and foreign policy issues which were prominent during the Truman administration

Eligibility: 1. Must be a graduate student or a postgraduate student 2. Must attend a university or a four-year college 3. Must not be attending high school currently 4. Must study full-time 5. Restricted to students studying History, Political Science, Women's Studies

Level of Study: Research

Type: Research grant

Value: US $\$ 2,500$ are awarded twice annually

Length of Study: 1-3 weeks

Frequency: Twice a year

Country of Study: Unrestricted

Application Procedure: Competitive proposals will evidence a clear understanding of the existing research in the field and how the proposed work adds significantly to that body of literature. Applicants are expected to demonstrate both an analytical and descriptive grasp of the project and its centrality to the Truman era. Application packages must include the following: completed Research Grant application; curriculum vitae (3 pages, maximum); project description and justification (5 pages, maximum); a list of specific files the candidate expects to access at the Harry S. Truman Library and Museum; and two letters of reference from persons familiar with the applicant's scholarly work, including one from the project advisor, if candidate is a graduate or postdoctoral student. Letters must be received by the deadline and mailed 
or emailed directly to the Grants Administrator by the referring individual

No. of awards offered: 25

Closing Date: 1 April

Funding: Foundation

No. of awards given last year: 15

No. of applicants last year: 25

Additional Information: Please visit www.trumanlibrar yinstitute.org/research-grants/research-grants/

\section{For further information contact:}

Truman Library Institute, 5151 Troost Avenue, Suite 300, Kansas City, MO 64110, United States of America.

Tel: $\quad$ (1) 8164001216

Fax: (1) 8164001213

Email: Lisa.Sullivan@TrumanLibraryInstitute.org

\section{Harry S Truman Library Institute Scholar's Award}

Eligibility: 1. Must be a postgraduate student 2. Must attend a university 3 . Must not be attending high school currently 4. Must study full-time 5. Restricted to students studying History, Political Science, Women's Studies

Level of Study: Postdoctorate

Type: Award

Value: US $\$ 30,000$

Application Procedure: Please check at trumanlibrar yinstitute.org/research-grants/scholars-award

Closing Date: 15 DECEMBER

Funding: Private

Additional Information: www.trumanlibraryinstitute.org/ research-grants/scholars-award/

\section{For further information contact:}

Truman Library Institute, 5151 Troost Avenue, Suite 300, Kansas City, MO 64110, United States of America.

Tel: $\quad$ (1) 8164001216

Fax: (1) 8164001213

Email: Lisa.Sullivan@TrumanLibraryInstitute.org

\section{Harvard Business School}

Soldiers Field, Boston, MA 02163, United States of America.

Tel: (1) 6174956555

Email: executive_education@hbs.edu

\section{Harvard University Master of Business Administration Scholarship in the United States of America}

Subjects: Business Administration

Purpose: Harvard MBA has been taught at one of the most prestigious universities in the world as one of the world's leading management programs. Once every two years, the Boustany MBA Harvard Bursary is awarded for a two-year program at Harvard Business School.

Eligibility: Candidates need an excellent academic background and a significant commitment. Even if the bursary can be granted to candidates from any country, the candidates from Lebanese origins will receive priority. Only upon receipt of an admission offer under the Harvard MBA program can applicants apply for a scholarship. During their Internship, students are required to work on a project which relates to one of the objectives of the Foundation. Students may also be required to work during their Internship with one of our partners.

Type: Scholarship

Value: US $\$ 95,000$ (US $\$ 47,500$ per year) towards tuition fees Length of Study: Two years

Frequency: Every 2 years

Study Establishment: Harvard University

Country of Study: United States of America

Application Procedure: Send your copy of your curriculum vitae to admissions@boustany-foundation.org with a photograph, GMAT scores, and acceptance letter from the University.

\section{Harvard Travellers Club}

PO Box 190, Canton, MA 02021, United States of America.

Tel: (1) 7818210400

Email: gpbdtes@shieldpdckdging.com

Website: www.travellersfund.org

Contact: George Bates

\section{Harvard Travellers Club Permanent Fund}

Purpose: To support research involving travel from which results can be obtained of permanent scientific and educational value

Eligibility: 1. Must be an undergraduate student, a graduate student or a postgraduate student 2 . Must attend a university or a four-year college 3 . Must be at least 18 years old 4 . Both full-time and part-time students

Level of Study: Doctorate, Graduate, Postdoctorate, Postgraduate, Predoctorate, Research, Unrestricted

Type: Grant 
Value: US $\$ 2,500$

Frequency: Annual

Country of Study: Worldwide

Application Procedure: Please check website for all details

No. of awards offered: 10

Closing Date: 1 February

Funding: Trusts

Contributor: Club membership contributions (no major contributor)

No. of awards given last year: 2

No. of applicants last year: 10

Additional Information: www.petersons.com/scholarship/ harvard-travellers-club-permanent-fund-111_151392.aspx

\section{For further information contact:}

170 Hubbard St., Lenox, MA 01240, United States of America.

Email: Jackdeary@harvardtravellersclub.org

\section{Health Canada}

Applied Research \& Analysis Directorate, Analysis \& Connectivity Branch, 15th Floor, Jeanne Mance Building, Tunney's Pasture, Ottawa, ON K1A 1B4, Canada.

\section{Tel: $\quad$ (1) 6139548549}

Email: nhrdpinfo@isdicp3.hwc.ca

Website: www.hc-sc.gc.ca

Contact: Information \& Resource Officer

The National Health Research and Development Programme (NHRDP) funds research with scientific merit to support the Federal Department of Health's mission and national health priorities, and researchers whose work will contribute to policy development and strategic planning. In general, the NHRDP funds research that relates to issues of concern to the federal government and to those that may be of concern to provincial and territorial health ministries pertaining to the health system and the promotion of population health.

\section{MSc Fellowships and PhD Fellowships}

Purpose: To provide support to highly qualified students who wish to undertake full-time research training leading to an MSc degree (or equivalent) or a $\mathrm{PhD}$ degree (or equivalent) Eligibility: Open to Canadian citizens or landed immigrants of high academic standing who hold an honours Bachelor's degree or a professional degree in a health field and are already engaged in a Master's or $\mathrm{PhD}$ program

Level of Study: Postgraduate

Type: A variable number of fellowships

Value: C\$19,800 per year

Frequency: Annual

Study Establishment: at universities or affiliated institutions

Country of Study: Canada

Closing Date: 1 March

Additional Information: Prior to application, candidates should obtain a copy of the Training Awards Guide. www. petersons.com/scholarship/harvard-travellers-club-

permanent-fund-111_151392.aspx

\section{For further information contact:}

Extramural Research Programs Directorate, Health Programs \& Services Branch, Health Canada, Ottawa, ON K1A 0S5, Canada.

Fax: (1) 6139547363

\section{Health Research Board (HRB)}

Research and Development for Health, 73 Lower Baggot Street, Dublin 2, Ireland.

Tel: $\quad$ (353) 12345000

Email: hrb@hrb.ie

Website: www.hrb.ie

Contact: The Research Grants Manager

The Health Research Board (HRB) comprises 16 members appointed by the Minister of Health, with eight of the members being nominated on the co-joint nomination of the universities and colleges. The main functions of the HRB are to promote or commission health research, to promote and conduct epidemiological research as may be appropriate at national level, to promote or commission health services research, to liaise and co-operate with other research bodies in Ireland and overseas in the promotion of relevant research and to undertake such other cognate functions as the Minister may from time to time determine.

\section{Primary Care Training and Enhancement - Physician Assistant Program}

Purpose: The purpose of the PCTE - PA Program is to increase the number of primary care physician assistants (PA), particularly in rural and underserved settings, and 
improve primary care training in order to strengthen access to and delivery of primary care services nationally

Eligibility: Eligible applicants must be academically affiliated PA training programs, accredited by the Accreditation Review Commission on Education for the Physician Assistant (ARC-PA). Domestic faith-based and community-based organizations, tribes and tribal organizations may apply for these funds, if otherwise eligible

Level of Study: Graduate

Type: Training award

Value: US $\$ 2,000,000$ (estimated total program funding); Award ceiling $\$ 300,000$ per year.

Frequency: Annual

Country of Study: Any country

Application Procedure: Links to the full announcement and online application process are available through grants.gov. check the website appropriately

Closing Date: 14 January

Funding: Private

Additional Information: Preference will be given to applicants that: 1 . Demonstrate a high rate for placing graduates in practice settings having the principal focus of serving residents of Medically Underserved Communities. 2. Demonstrate a significant increase in the rate of placing graduates in Medically Underserved Community settings over the preceding 2 years. www.ruralhealthinfo.org/funding/4519

\section{For further information contact:}

Tel: (1) 3014437271

Email: SCicale@hrsa.gov

\section{Research Leaders Awards}

Eligibility: All applications must involve a partnership with at least one health-related partner organization involved in the delivery of health and social care and/or health and social care policy. Applications should be aligned with the strategic plans of the nominating organizations, and should reflect national priorities and strategies in health and social care

Level of Study: Doctorate, Postdoctorate

Type: Award

Value: The awards will be for up to $£ 1,000,000$, for staff salaries and associated costs

Length of Study: A maximum of 5 years

Frequency: Annual

Country of Study: Ireland

Application Procedure: All applications must be made online using the HRB GEMS. To access the application form the nominating Higher Education Institution must provide the HRB with the contact details of their nominated Principal Investigator. The HRB will then invite the nominated candidate to initiate the application form

Closing Date: 31 March
Funding: Government

Additional Information: Please check at www.hrb.ie/ research-strategy-funding/grants-and-fellowships/hrb-grantsand-fellowships/grant/133

\section{For further information contact:}

Email: ferrism@queensu.ca

\section{Hearst Corporation}

801 Texas Avenue, Houston, TX 77002, United States of America.

Email: kenn.altine@chron.com

Website: www.hearstfellowships.com

Hearst Corporation is one of the largest diversified communications companies.

\section{Hearst Fellowships}

Purpose: To help develop excellent reporters, editors, photographers, designers and graphic artists

Eligibility: Open to candidates who are graduates and have experience or background in journalism or related fields

Level of Study: Professional development

Type: Fellowships

Value: Varies

Length of Study: 2 years

Frequency: Annual

Country of Study: Any country

Application Procedure: The applicants must download the application form from the website. The completed application form along with other enclosures is to be sent to Hearst Fellowships

Closing Date: 1 December

For further information contact:

Email: fellowships@hearstnp.com

\section{Heart and Stroke Foundation}

Suite 1402, 222 Queen Street, Ottawa, ON K1P 5V9, Canada.

Tel: $\quad$ (1) 6135694361

Email: research@hsf.ca

Website: www.heartandstroke.ca 
The Heart and Stroke Foundation is involved in eliminating heart disease and stroke and reducing their impact through the advancement of research and its application, and advocacy for the promotion of healthy living. It is a federation of 10 provincial foundations, led and supported by a force of more than 140,000 volunteers.

\section{Canada Doctoral Research Award}

Purpose: To award highly qualified graduate students enrolled in a $\mathrm{PhD}$ program, undertaking full-time research training in the cardiovascular or cerebrovascular fields

Eligibility: Open to students enrolled in a PhD program and must be a full-time medical student

Level of Study: Doctorate, Research

Type: Research

Value: C\$21,000

Country of Study: Canada

Application Procedure: Applicants must send the application form along with the transcript, essay references and a self-addressed stamped envelope

Closing Date: 1 November

\section{For further information contact:}

Research Department, Room 9A-27, Parklawn Building, 5600 Fishers Lane, Rockville, MD 20857, United States of America.

Tel: $\quad$ (1) 6135694361 ext. 327

Fax: (1) 6135693278

Email:1hodgson@hsf.ca

\section{Career Investigator Award}

Purpose: To support established independent researchers who wish to make research their full-time career (Ontario applicants only)

Eligibility: Awards for individuals with an $\mathrm{MD}, \mathrm{PhD}$ or equivalent degree working in the field of cardiovascular and/or cerebrovascular disease who wish to make their research a full-time career. Applicants must provide proof of national recognition

Level of Study: Postgraduate

Type: Scholarship

Value: Stipend C\$81,500 per year, C\$1,500 per year for travel, and minimum C\$48,282 for scientific purpose

Application Procedure: Applicants must send the application form along with the transcript, essay references and a self-addressed stamped envelope and must provide proof of national recognition

Closing Date: 1 September
Contributor: Heart and Stroke Foundations of Ontario and British Columbia and the Yukon

Additional Information: For more details see website or contact the foundation. www.hrb.ie/fileadmin/2. Plugin related_files/Funding_schemes/Research_Leader_Awards_ 2020_Guidance_Notes.pdf

\section{Dr Andres Petrasovits Fellowship in Cardiovascular Health Policy Research}

Eligibility: Please visit the website

Level of Study: Postgraduate

Type: Fellowship

Value: C\$70,000

Length of Study: 3 years

Application Procedure: Please contact the foundation for application form

\section{Grants-in-Aid of Research and Development}

Purpose: To support researchers in projects of experimental nature in cardiovascular or cerebrovascular development

Eligibility: Open for full-time medical student

Level of Study: Postgraduate

Type: Grant

Value: Approx. C\$33,000,000

Frequency: Every 3 years

Application Procedure: Applicants must send the application form along with the transcript, essay references and a self-addressed stamped envelope

Closing Date: 27 August

Additional Information: Please check website for more details. www.hrb.ie/fileadmin/2._Plugin_related_files/Funding_ schemes/Research_Leader_Awards_2020_Guidance_Notes.pdf

\section{Heart and Stroke Foundation of Canada Doctoral Research Award}

Purpose: To support individuals enroled in a $\mathrm{PhD}$ program and undertaking full-time research training in the stroke field Eligibility: Applicants must be Canadians studying abroad or in Canada or for foreign visitors to Canada. The fellowship is open to citizens of United States

Level of Study: Postgraduate

Type: Fellowship

Value: Varies

Country of Study: Canada

Application Procedure: Applicants must send the application form along with the transcript, essay references and a self-addressed stamped envelope

Closing Date: 1 November 


\section{For further information contact:}

Heart and Stroke Foundation of Canada, 1037 Topsail Rd, Mount Pearl, NL A1N 5E9, Canada.

Tel: $\quad$ (1) 6135694361 ext. 268

Fax: (1) 6135693278

Email: anguyen@hsf.ca

\section{Heart and Stroke Foundation of Canada New Investigator Research Scholarships}

Eligibility: 1. Must be a graduate student or a postgraduate student 2. Must attend a university 3. Citizenship requirements: Canada 4. Must not be attending high school currently 5. Must study full-time 6 . Restricted to students studying Health and Medical Sciences

Level of Study: Postgraduate

Type: Scholarship

Value: Maximum C\$30,000

Application Procedure: Applicants must send the application form along with the transcript, essay references and a self-addressed stamped envelope

Closing Date: 1 September

Additional Information: www.petersons.com/scholarship/ heart-and-stroke-foundation-of-canada-new-investigator-111 151415.aspx

\section{For further information contact:}

1525 Carling Avenue, Suite 110, Ottawa, ON K1Z 8R9, Canada.

Tel: $\quad$ (1) 6135694361

Email: research@heartandstroke.ca

\section{Heart and Stroke Foundation of Canada Nursing Research Fellowships}

Eligibility: Applicants must possess a nursing degree. For master's degree candidates, the programmes must include a thesis or project requirement

Level of Study: Postgraduate

Type: Fellowship

Value: Minimum C\$18,570

Country of Study: Canada

Application Procedure: Applicants must send the application form along with the transcript, essay references and a self-addressed stamped envelope

Closing Date: 14 March

Additional Information: Please check website for more details. www.petersons.com/scholarship/heart-and-strokefoundation-of-canada-new-investigator-111_151415.aspx
For further information contact:

Research Department, 222 Queen Street, Suite 1402, Ottawa, ON K1P 5V9, Canada.

Tel: $\quad$ (1) 6135694361 ext. 327

Fax: (1) 6135693278

Email: lhodgson@hsf.ca

\section{Heart and Stroke Foundation of Canada Research Fellowships}

Eligibility: Applicants must possess a full-time degree for study towards an MSc or $\mathrm{PhD}$.

Level of Study: Postgraduate

Type: Fellowship

Value: C\$25,998 (minimum) and C\$33,426 (maximum)

Country of Study: Canada

Application Procedure: Applicants must send the application form along with the transcript, essay references and a self-addressed stamped envelope

Closing Date: 1 November

\section{Heart Research United Kingdom}

Suite 12D, Joseph's Well, Leeds LS3 1AB, United Kingdom.

Tel:

(44) 1132347474

Email: mail@heartresearch.org.uk

Website: www.heartresearch.org.uk

Contact: Helen Wilson, Senior Research Officer

Heart Research United Kingdom funds pioneering medical research into the prevention, treatment and cure of heart disease. Heart Research United Kingdom is a visionary charity leading the way in funding ground-breaking, innovative medical research projects at the cutting edge of science into the prevention, treatment and cure of heart disease. There is a strong emphasis on clinical and surgical projects and young researchers. Heart Research United Kingdom encourages and supports original health lifestyle initiatives exploring novel ways of preventing heart disease in all sectors of the community.

\section{Heart Research United Kingdom Translational Research Project Grants}

Purpose: To support ground-breaking, innovative medical research into prevention, treatment and cure of heart disease and related conditions 
Eligibility: Graduates or those holding a suitable professional qualification. Research must be carried out in the United Kingdom at a university, hospital or other recognized research institution

Level of Study: Research, Unrestricted

Type: Project grant

Value: $£ 200,000$

Length of Study: Up to 3 years

Frequency: Annual

Study Establishment: Centres of health and educational establishments

Country of Study: United Kingdom

Application Procedure: Information and application forms available at heartresearch.org.uk/grants/translationalresearch-project-trp-grants

No. of awards offered: 45

Closing Date: 1 June

Funding: Corporation, Foundation, Individuals, Private, Trusts

Contributor: Voluntary funding from supporters and grantmaking trusts

No. of awards given last year: 6

No. of applicants last year: 45

Additional Information: Please note that the HRUK office is closed on Saturdays and Sundays and therefore deliveries cannot be accepted at the weekend. heartresearch.org.uk/trpapply/

\section{For further information contact:}

Heart Research UK, Suite 12D, Joseph's Well, Leeds LS3 $1 \mathrm{AB}$, United Kingdom.

Email: research@heartresearch.org.uk

\section{Heinrich Boll Foundation}

Heinrich-Böll-Stiftung e.V. Schumannstr. 8, D-10117 Berlin, Germany.

Tel:

$$
\text { (49) } 3028534400
$$

Email:_studienwerk@boell.de

Website: www.boell.de/en

Fostering democracy and upholding human rights, taking action to prevent the destruction of the global ecosystem, advancing equality between women and men, securing peace through con-flict prevention in crisis zones, and defending the freedom of individuals against excessive state and economic power - these are the objectives that drive the ideas and actions of the Heinrich Böll Foundation. We maintain close ties to the German Green Party (Alliance 90/The Greens) and as a think tank for green visions and projects, we are part of an international net-work encompassing well over 100 partner projects in approximately 60 countries. The Heinrich Böll Foundation works independently and nurtures a spirit of intellectual openness. We maintain a world-wide network with currently 30 international offices. We co-operate closely with 16 state-level Böll Foundations in each of Germany's federal states, and we support talented, socio-politi-cally engaged undergraduate and graduate students in Germany and abroad. We gladly follow Heinrich Böll's exhortation for citizens to get involved in politics, and we want to inspire others to do the same.

\section{Heinrich Boll Scholarships in Germany for International Students}

Purpose: The Heinrich Böll Foundation awards some scholarships to international students who gained their university entrance qualification from a school outside of Germany who wish to study a Masters or PhD Degree in Germany.

Eligibility: International Master students who earned their university entrance qualification outside Germany: You may apply before commencing your Masters programme or at any time up to the end of the first semester of the Masters programme. Proof of first professional qualification must be provided, International Doctoral students who earned the university entrance qualification outside Germany: The applicant must have been accepted as a doctoral student by a state or state-recognised university in Germany. Proof of admission, as a rule in Germany, must be included with the application. By the application date, preliminary work must have been completed and a valid timetable for completion must be submitted. PhD subjects related to focal points of the Foundation's activities will be given priority.

Level of Study: Masters Studies/ PhD Studies

Type: Scholarships

Value: Masters Studies: Non-EU students: $€ 850$ per month plus various individual allowances; tuition fees are in certain cases possible in Germany. EU students: varies, max. $€ 649$ plus $€ 300$ book money per month; tuition fees not possible in Germany but possible to a limited extent in other countries. The scholarship is awarded for the regular period of study, may be extended by one semester. PhD Studies: Non-EU students: $€ 1,200$ per month plus $€ 100$ mobility allowance per month, plus various individual allowances; tuition fees are not possible. EU students: $€ 1,350$ per month basic scholarship plus $€ 100$ per month research costs allowance; tuition fees are not possible in Germany but possible to a limited extent in other countries. The scholarship is awarded for two years as a rule, may be extended twice at most by half a year.

Frequency: Annual

Country of Study: Germany 
Application Procedure: For details of application requirements and procedures, please consult information sheet A 1-1 ("scholarship application for undergraduate and graduate students", PDF) or A 2-1 ("scholarship application for doctoral studies"). The online application portal closes on 1 March at the latest. It is important to visit the official website (link found below) for details on how to apply for this scholarship. Closing Date: 1 March

Additional Information: www.boell.de/en/foundation/ application

\section{Helen Hay Whitney Foundation}

\section{Postdoctoral Research Fellowship}

Subjects: Biomedical sciences

Purpose: To attain its ultimate goal of increasing the number of imaginative, well-trained and dedicated medical scientists, the Foundation grants financial support of sufficient duration to help further the careers of young men and women engaged in biological or medical research.

Eligibility: Candidates who hold, or are in the final stages of obtaining a PhD, M.D., or equivalent degree and are seeking beginning postdoctoral training in basic biomedical research are eligible to apply for a fellowship. The Foundation accepts applications from candidates who have no more than one year of postdoctoral research experience at the time of the deadline for submitting the application (June 15), and who have received a $\mathrm{PhD}$ (or D.Phil. or equivalent) degree no more than two years before the deadline, or an M.D. degree no more than three years before the deadline. Fellowships may be awarded to US citizens planning to work in laboratories either in the US, Canada, or abroad and also to foreign citizens for research in laboratories in the US only. We expect that most applicants will reside in North America at the time of application. Foreign Students will need to obtain appropriate visa documentation, as required by US Immigration. Applications from established scientists or advanced fellows will not be considered. The fellowships are for early postdoctoral training only. Clinical house-staff training does not count as postdoctoral laboratory training. The Foundation will not ordinarily consider applicants who plan tenure of the fellowship in the laboratory in which they have already received extensive predoctoral or postdoctoral training. The aim of the fellowship is to broaden postdoctoral training and experience, and a significant change of venue is advisable. Since the number of available fellowships is limited, the Foundation does not make more than one award per year for training with a given supervisor. It also does not support more than two fellows per laboratory at one time.

Type: Fellowship

Value: Up to US\$54,000 in the first year; US\$57,000 in the second and US\$60,000 in the third, plus a US\$1,500 annual research allowance. There is a Dependent Child Allowance of US\$1,500 per annum for each child. There is no allowance for a spouse.

Length of Study: Three years

Country of Study: Any country

Application Procedure: Applications are to be filled out and submitted online at www.hhwf.org.

Closing Date: 15 June

Additional Information: Apply online. hhwf.org/researchfellowship/

\section{Research Fellowship}

Subjects: biological or medical research

Purpose: Foundation grants financial support of sufficient duration to help further the careers of young men and women engaged in biological or medical research

Eligibility: Fellowships may be awarded to US citizens planning to work in laboratories either in the US, Canada, or abroad and also to foreign citizens for research in laboratories in the US only. We expect that most applicants will reside in North America at the time of application. Foreign Students will need to obtain appropriate visa documentation, as required by US Immigration.

Level of Study: Research

Type: Grant

Value: research allowance of $\$ 1,500$

Length of Study: 3 years

Frequency: Annual

Country of Study: United Kingdom

Application Procedure: Applications are to be filled out and submitted online at www.hhwf.org

Closing Date: 15 June

Funding: Foundation

Additional Information: Late applications will not be considered

\section{Hellenic Pasteur Institute}

Vas Sofias Avenue 127, GR-11521 Athens, Greece.

Tel: $\quad$ (30) 16478800

Website: www.pasteur.gr

Contact: Dr S Tzartos

\section{W.D.E. Coulson \& Toni M. Cross Aegean Exchange Program}

Purpose: The purpose of these fellowships is to provide an opportunity for Greek scholars to meet with their Turkish 
colleagues, and to pursue research interests in the museum, archive, and library collections and at the sites and monuments of Turkey

Eligibility: The library at ARIT-Istanbul includes approximately 14,000 volumes and covers the Byzantine, Ottoman, and modern Turkish periods. Archives, libraries, sites, and museums in Turkey provide resources for research into many fields of study and geographical areas

Level of Study: Postdoctorate

Type: Fellowship

Length of Study: From two weeks to two months

Frequency: Annual

Country of Study: Any country

Application Procedure: 1. Stipend of US\$250 is required. 2. Submit "Associate Membership with Fellowship" application online. 3. The application should include a curriculum vitae, statement of the project to be pursued during the period of grant (up to three pages, single-spaced in length), two letters of reference from scholars in the field commenting on the value and feasibility of the project

Funding: Private

Additional Information: ascsa.submittable.com/submit/ 115754/elizabeth-a-whitehead-distinguished-scholars-applica tion-form hellenicstudies.gsu.edu/2019/01/21/w-d-e-coulsontoni-m-cross-aegean-exchange-program/

\section{Help Musicians United Kingdom}

\section{POP Awards}

Purpose: Help Musicians' postgraduate awards offer support to students who wish to complete their studies at the leading UK conservatoires and performing arts colleges

Level of Study: Postgraduate

Type: Award

Value: $£ 40,000$

Length of Study: 2 year

Frequency: Annual

Country of Study: Any country

Closing Date: 1 March

\section{For further information contact:}

Email: creative@helpmusicians.org.uk

\section{Postgraduate Awards}

Purpose: Help Musicians' postgraduate awards offer support to students who wish to complete their studies at the leading UK conservatoires and performing arts colleges.

Level of Study: Postgraduate
Type: Award

Value: $£ 5,000$

Length of Study: Annual Awards

Frequency: Annual

Country of Study: United Kingdom

Application Procedure: Must have lived in United Kingdom for 3 consecutive years by Postgraduate start date. Applications made via online application form

No. of awards offered: 140

Closing Date: 1 March

Funding: Private

Contributor: Help Musicians United Kingdom

No. of awards given last year: 450

No. of applicants last year: 140

\section{For further information contact:}

Tel: $\quad$ (44) 2072399119

Email: creative@helpmusicians.org.uk

\section{Sybil Tutton Awards}

Purpose: Help Musicians launched the Sybil Tutton Opera Awards to help opera students with the costs of postgraduate study.

Eligibility: This year our awards are open to students who are hoping to start a postgraduate degree or move in to a second year of postgraduate

Level of Study: Postgraduate

Type: Award

Value: $£ 1,000-5,000$

Frequency: Annual

Country of Study: Any country

Application Procedure: Application is by nomination only from head of voice at the United Kingdom conservatoires and the National Opera Studio

Closing Date: 1 March

For further information contact:

Email: awards@helpmusicians.org.uk

\section{Transmission Fund}

Purpose: We want our support to make a real difference to you and your career, so you are free to specify opportunities relevant to your own circumstances and ambitions - whether it's a course or 1-on-1 time you need to hone your skills, we can help you to feel confident in making your next move Eligibility: 1. Be aged over 182 . Have been resident in the UK for at least 3 consecutive years 3 . Help Musicians refers to the UK residency rules noting that you are eligible for our support: 1. If you are a UK National living in the UK you automatically 
qualify 2. If you are a non-UK National, you have been living in the UK for at least 183 days and have the legal right to live in the UK 4. Already have an active career in music

Type: Funding support

Frequency: Annual

Country of Study: Any country

Closing Date: 12 April

\section{Henry Moore Institute}

The Headrow, Leeds LS1 3AH, United Kingdom.

Tel: $\quad$ (44) 1132467467

Email: kirstie@henry-moore.org

Website: www.henry-moore.org

Contact: Kirstie Gregory, Research Programme Assistant

The Henry Moore Institute is a world-recognized centre for the study of sculpture. The institute hosts exhibitions, conferences and lectures, as well as developing research to expand the understanding and scholarship of historical and contemporary sculpture.

\section{Henry Moore Institute Research Fellowships}

Purpose: To enable scholars to use the Institute's facilities, which include the sculpture collection, library, archive and slide library, to assist them in researching their particular field

Eligibility: There are no restrictions

Level of Study: Doctorate, Postdoctorate, Postgraduate, Research

Type: Fellowship

Value: Accommodation, travel and daily living expenses

Length of Study: 1 month

Frequency: Annual

Study Establishment: The Henry Moore Institute

Country of Study: United Kingdom

Application Procedure: Applicants must send a letter of application, a proposal (maximum 1,000 words) and a curriculum vitae. Visit the website

No. of awards offered: 80

Closing Date: 12 January

Funding: Foundation

Contributor: The Henry Moore Foundation

No. of awards given last year: 4

No. of applicants last year: 80

Additional Information: www.henry-moore.org/grants/ grants-programme/research-fellowships

\section{Henry Moore Institute Senior Fellowships}

Purpose: Senior fellowships are intended to give established scholars (working on any aspect of sculpture) time and space to develop a research project free from their usual work commitments

Level of Study: Doctorate, Postdoctorate

Type: Fellowship

Value: Fellowships provide accommodation, travel expenses, and a per diem

Length of Study: 3-6 weeks

Frequency: Annual

Study Establishment: Henry Moore Institute

Country of Study: United Kingdom

Application Procedure: Full details are available from the website www.henry-moore.ac.uk

No. of awards offered: 15

Closing Date: 12 January

Funding: Foundation

Contributor: Henry Moore Foundation

No. of awards given last year: 1

No. of applicants last year: 15

Additional Information: Research fellowships are also available. The institute offers the possibility of presenting finished research in published form as a seminar or as a small exhibition www.henry-moore.org/grants/grantsprogramme/research-fellowships

\section{Herb Society of America, Inc.}

9019 Kirtland Chardon Road, Kirtland, OH 44094, United States of America.

Tel: (1) 4402560514

Email:_herbs@herbsociety.org

Website: www.herbsociety.org

Contact: Ms Michelle Milks, Office Administrator

The aim of the Herb Society of America Inc. is to promote the knowledge, use and delight of herbs through educational programmes, research and sharing the experience of its members with the community.

\section{Herb Society of America Research Grant}

Purpose: To further the knowledge and use of herbs and to contribute the results of study and research to the records of horticulture, science, literature, history, art or economics 
Eligibility: Open to persons with a proposed programme of scientific, academic or artistic investigation of herbal plants Level of Study: Unrestricted

Value: Up to US $\$ 5,000$

Length of Study: Up to 1 year

Frequency: Annual

Country of Study: Any country

Application Procedure: Applicants must submit an application clearly defining all their research in 500 words or less and a proposed budget with specific budget items listed. Requests for funds will not be considered unless accompanied by five copies of the application form and proposal. The application must be submitted in electronic form via email to herbs@herbsociety.org

Closing Date: 31 January

Contributor: Members

Additional Information: Finalists will be interviewed. In order to complete the application, use the below link. herbsocietyorg.presencehost.net/support/grants-scholarships/ application-for-the-hsa-research-grant.html grad.uchicago. edu/fellowship/herb-society-of-america-research-grant/

\section{Heriot-Watt University}

Postgraduate Admissions Office, Edinburgh EH14 4AS, United Kingdom.

\section{Tel: $\quad$ (44) 1314495111}

Email: edu.liaison@hw.ac.uk

Website: www.hw.ac.uk

Contact: Fiona Watt, Wider Access Assistant

Heriot-Watt University, one of the oldest higher education institutions in the United Kingdom, is Scotland's most international university. Our six academic schools and two postgraduate institutes offer research opportunities and postgraduate taught programmes in science and engineering, business, languages and design. We disburse over $£ 6 \mathrm{M}$ in fee and stipend scholarships annually.

\section{Mexican Scholarships}

Purpose: Financial assistance for Mexican students in science, engineering and technology

Eligibility: Mexican citizens

Level of Study: Postgraduate

Type: Scholarship

Value: Tuition fees and living costs

Frequency: Annual
Study Establishment: Heriot-Watt University

Country of Study: Scotland

Application Procedure: Contact Bob Tuttle

Funding: Government

Contributor: Heriot-Watt and CONACYT (Mexican

National Council for Science and Technology)

\section{For further information contact:}

Tel: (44) 1314513746

Email: b.tuttle@hw.ac.uk

\section{Music Scholarships}

Purpose: To support musicians in obtaining a postgraduate qualification whilst developing their musical skills

Eligibility: All instrumentalists and vocalists who have been accepted for a course. The following criteria are taken into consideration: musical ability and potential, proof of exam results and membership of orchestras or choirs; a reference from your last vocal or instrumental teacher; in the case of the Archer Music Scholarships, a personal statement is also required; auditions will be held during Semester 1

Level of Study: Postgraduate, Research

Type: Scholarship

Value: free music tuition for talented singers and instrumentalists, up to a value of $£ 400$ per year and talented musician to receive music tuition up to a value of $£ 500$

Length of Study: 1 year

Frequency: Annual

Study Establishment: Heriot-Watt University

Country of Study: Scotland

Application Procedure: For an application form or more information please contact Steve King MBE, Director of Music

Additional Information: There will be a music scholar's concert in HWU in March each year at which all music scholars are all expected to participate. www.hw.ac.uk/news. $\mathrm{htm}$

\section{For further information contact:}

Tel: (44) 1314513705

Email: s.king@hw.ac.uk

\section{Overseas Research Students Awards Scheme (ORSAS)}

Purpose: Assist international postgraduate research students with payment of tuition fees

Eligibility: Non-European Union research applicants

Level of Study: Research 
Type: Scholarship

Length of Study: 3 years

Frequency: Annual

Study Establishment: Heriot-Watt University

Country of Study: Scotland

Application Procedure: Apply to School of Study

Closing Date: 30 November

Contributor: Heriot-Watt University

Additional Information: Successful applicants usually receive James Watt Scholarships for the remainder of their fees plus a maintenance contribution. www.hw.ac.uk/news.htm

\section{For further information contact:}

Email: pgadmissions@glasgow.ac.uk

\section{Postgraduate Merit Award}

Purpose: We aim to encourage well-qualified, ambitious students to study with us and we offer a wide variety of scholarships and bursaries to achieve this. Over $£ 6$ million worth of opportunities are available in fee and stipend scholarships, and more than 400 students benefit from this support. Eligibility: 1. Domiciled in one of the countries listed above at the time of application and classified as an overseas student for fee purposes starting a full-time on-campus programme of study. 2. Self-funding your course. 3. Holding an offer to study a full-time postgraduate taught degree course starting in September 2020.

Level of Study: Postgraduate

Type: Scholarship

Value: $£ 1,500$ - $£ 3,000$

Frequency: Annual

Application Procedure: You will be automatically considered for the scholarship if you meet the academic criteria.

No. of awards offered: Multiple

Closing Date: September

Additional Information: www.hw.ac.uk/study/scholarships/ postgraduate-merit-award.htm

For further information contact:

EH14 4AS Edinburgh, Scotland, United Kingdom.

\section{Higher \& Education South Africa}

\section{Africa: Mwalimu Julius Nyerere African Union Scholarship}

Purpose: Mwalimu Julius Nyerere African Union Scholarship is intended to enable young Africans to study at reputable African universities with a binding agreement that scholarship beneficiaries will work in any African country for at least the same duration of the scholarship period after graduation. The scholarship aims to provide an opportunity to enhance knowledge, professional skills and capacity of refugees and displaced people, in order to streamline their integration to contribute towards sustainable development in Africa

Eligibility: 1. Applicants must be a citizen of an African Union Member State. 2. Must be a formally registered refugee/displaced person with a UNHCR registration number or be able to demonstrate confirmed refugee status in an African Union Member State. 3. Must be under the age of thirty five (35) years. 4. Must be a holder of a Bachelor's degree in the relevant field, at least at the level of Upper Second class Honours. The degree must be from a recognised university. 5. Must have demonstrated outstanding academic achievement as evidenced by academic transcripts, and academic awards if any. 6. Have proof of admission to undertake a full time Master's programme in a recognized university in an African Union Member State. 7. Be willing to commit to work in an African Union Member State on completion of studies for at least three (3) years

Level of Study: Postgraduate

Type: Scholarship

Value: Stipend to the value of R500 monthly to cover accommodation, meals, utilities, local transport and medication, Travel allowance: once-off R250, R350 to assist with shipping and other terminal expenses, Computer allowance: R1,000

Frequency: Annual

Country of Study: South Africa

Application Procedure: Apply online www.edu-au.org/ scholarshipg

Closing Date: 30 April

Funding: Foundation

\section{For further information contact:}

Department of Human Resources, Science and Technology, African Union Commission, PO Box 3243, Addis Ababa, Ethiopia, Eastern Africa.

Tel: $\quad$ (251) 115517700

Fax: (251) 115517844

Email: internationalscholarships@dhet.gov.za

\section{Africa: Next Einstein Forum (NEF) Fellows Programme}

Purpose: The Next Einstein Forum (NEF) is an initiative of the African Institute for Mathematical Sciences (AIMS) in partnership with the Robert Bosch Stiftung. The NEF is a platform that connects science, society and policy in Africa 
and the rest of the world - with the goal to leverage science for human development globally. The Fellows Programme consists of Africa's most brilliant young scientists that the NEF showcases on the global stage. The Programme provides Fellows with the opportunity to present their research and draw upon the vast networks of NEF members and participants for support, connections and advice to advance their work

Eligibility: 1. Africans from around the world - including those who currently reside in the Diaspora. 2 . Hold a passport from an African country. 3. Hold a PhD in a field of science, Technology, Engineering, Mathematics or the social sciences. 4. Have a demonstrated track record of research/findings that have global impact. 5. You are passionate about raising Africa's profile in STEM globally. 6. Able to clearly present their work to an audience in English or French

Level of Study: Postgraduate

Type: Fellowship

Frequency: Annual

Country of Study: South Africa

Closing Date: 27 January

Funding: Foundation

Additional Information: www.afterschoolafrica.com/ 17391/next-einstein-forum-fellowship/

\section{For further information contact:}

NEF Secretariat, c/o AIMS-NEI 590 KG ST Gasabo, Kigali, Rwanda.

Email: info@nef.org

\section{Austria: Erasmus+ Master in Research and Innovation in Higher Education (MARIHE) Programme}

Purpose: The Master in Research and Innovation in Higher Education (MARIHE) is supported by the Erasmus+ Programme of the European Union (EU) under the action of an Erasmus Mundus Joint Master Degree (EMJMD)

Eligibility: 1. Must hold a first university degree, this should be at least a Bachelor degree issued by a university, quantified as three years of studies corresponding. 2. Show a strong motivation and interest. 3. Have sufficient knowledge of English for academic purposes

Level of Study: Postgraduate

Type: Grant

Frequency: Annual

Country of Study: South Africa

Application Procedure: Apply online: www.marihe.eu/howto-apply/application-process-and-timetable

Closing Date: 5 December

Funding: Private

\section{For further information contact:}

Email: marihe@donau-uni.ac.at

\section{Azerbaijan: Non-Aligned Movement (NAM) Scholarship}

Purpose: The Government of the Republic of Azerbaijan is offering scholarships for Bachelor's, Master's and Doctoral programmes to the citizens of Non-Aligned Movement (NAM) countries (including South Africa)

Eligibility: 1. Citizen of Non-Aligned Movement (NAM) countries (this includes South Africa) 2. For undergraduate programmes applicants must be younger than 25 years old 3. For Master's programmes applicants must be younger than 30 years old 4 . For doctoral programmes applicants must be younger than 40 years old

Level of Study: Postgraduate

Type: Scholarship

Value: Value of AZN 800

Frequency: Annual

Country of Study: South Africa

Application Procedure: Apply: www.internationalscholar ships.dhet.gov.za/Application\%20form.pdf

Closing Date: 8 February

Funding: Foundation

Additional Information: www.internationalscholarships. dhet.gov.za/AZERBAIJANNon-AlignedMovement(NAM) Scholarship202021.html

\section{For further information contact:}

Tel: $\quad$ (994) 125969296

Email: scholars@mfa.gov.az

\section{Brunei Darussalam: Government of Brunei Darussalam Scholarship}

Purpose: The Brunei Darussalam Ministry of Foreign Affairs invites applications for the Government of Brunei Darussalam Scholarship. The scholarship is tenable at higher education institutions in Brunei Darussalam and provides applicants with an opportunity to pursue Diploma, Bachelor's and Master's degrees

Eligibility: 1. Applicant must be citizen of Pakistan/AJK 2. Must be between the ages of 18-25 for undergraduate programmes 3. Age should not exceed from 35 years for candidates who are applying for Postgraduate programmes. 4. Applicants having 3rd division in their academic career are eligible to apply but NOT in the terminal degree. 5. The applicant must have completed HSSC/Intermediate or equivalent for application to 04 year Bachelor Program. 6. The applicant must have completed 16 years education or 
(04 years) Bachelors/equivalent Degree for application to Postgraduate Masters Program. 7. Certificates/Transcript/ Degrees to be attached must be attested by the attesting authorities such as IBCC and HEC. Equivalence of O \& A level is mandatory by IBCC. 8 . The applicant must provide Health certificate with his application. 9. IELTS/TOEFL scores are required, where applicable.

Level of Study: Postgraduate

Type: Scholarship

Value: BND250.00 to a country within the asean region; or BND500.00 to a country outside the asean region

Frequency: Annual

Country of Study: South Africa

Application Procedure: Apply online: www.ubd.edu.bn/ admission/scholarships.html

No. of awards offered: Several

Closing Date: 14 February

Funding: Foundation

Additional Information: www.afterschoolafrica.com/11428/ brunei-darussalam-government-scholarships/

\section{For further information contact:}

Assistant Director, Learning Opportunities Abroad (LOA), HRD Division, Higher Education Commission, Sector H-8, Islamabad, Pakistan.

Tel: $\quad$ (92) 51111119432

Email: applyBDGS2020@mfa.gov.bn

\section{China: Chinese Government Scholarship}

Purpose: The Chinese Government is offering scholarships for South African students to study at Chinese institutions. The Department of Higher Education and Training is responsible for nominations

Eligibility: Listed below are the eligibility factors for the scholarship: 1. South African citizens in good health (medical check will be required for successful applicants). 2. Strong academic record with a minimum $65 \%$ average in previous studies. 3. Demonstrated interest in China and commitment to the development of South Africa. 4. Applications in all fields of study except medicine will be considered. 5. Preference will be given to postgraduate applicants, previously disadvantaged applicants and applications in the following fields. The scholarship is offered for undergraduate (Bachelors) in the identified scarce skills, postgraduate (Masters or $\mathrm{PhD}$ ) or non-degree Chinese language studies. Bachelor's degree scholarships are taught in Chinese and will only be awarded to applicants who already have the required level of Chinese proficiency
(HSK 5 or above). Preference is given to applications for postgraduate studies

Level of Study: Postgraduate

Type: Scholarship

Frequency: Annual

Country of Study: South Africa

Application Procedure: Apply online: www.campuschina. org/universities/index.html

Closing Date: 15 March

Funding: Foundation

\section{For further information contact:}

Level 13, Building A3 No. 9 Chegongzhuang St, Dong Wu Yuan, Xicheng Qu, CN 100738 Beijing Shi, China.

Email: internationalscholarships@dhet.gov.za

\section{China: One Belt One Road Scholarship}

Purpose: Peking University Guanghua School of Management is offering One Belt One Road Scholarship to pursue an MBA programme at Peking University. The International MBA programme is a full-time (2 years) English-taught programme

Eligibility: 1. Applicants must hold a non-Chinese citizenship and be citizens from Belt and Road Initiative (BRI) countries. 2. Must hold a Bachelor's degree equivalent to a Bachelor's degree in China. 3. Must have two or more years of relevant full-time work experience. 4. Must obtain a competitive score from the Guanghua MBA entrance exam. 5. Must have leadership quality

Level of Study: Postgraduate

Type: Scholarship

Value: Accommodation subsidy (RMB 4,000/person/month), Living allowance (RMB 3,000/person/month), edical insurance fee (RMB 800/person/year), Application fee of RMB 800 will be waived

Length of Study: 2 year

Frequency: Annual

Country of Study: South Africa

Application Procedure: Apply online: applymba.pku.edu. $\mathrm{cn} /$. The One Belt One Road Scholarship will not only provide the opportunity to study at Peking University which is one of the most prestigious universities in China, and is ranked \#1 in China and \#2 in the Asia-Pacific region by Times Higher Education World University Rankings, but also a chance to become an expert in China affairs and gain a solid foothold in the China market

Closing Date: September

Funding: Private 


\section{For further information contact:}

Tel: $\quad$ (86) 15010656075

Email: yul@gsm.pku.edu.cn

\section{China: Renmin University Master of Contemporary Chinese Studies Scholarship}

Purpose: The Silk Road School at the Renmin University of China (Suzhou) offers scholarships to foreign students who wish to pursue a Master of Contemporary Chinese studies at Renmin University of China (Suzhou)

Eligibility: 1. Be foreign citizens who have interest in Belt and Road Initiative (BRI) and Chinese culture. 2. Have the ability to speak, read and write English at an equivalent score of IELTS 6.5 or TOEFL 90

Level of Study: Postgraduate

Type: Scholarship

Frequency: Annual

Country of Study: South Africa

Application Procedure: Apply online www.rdcy.org/ displaynewsen.php?id=45928

Closing Date: 10 June

Funding: Foundation

Additional Information: www.internationalscholarships. dhet.gov.za/china\%20-\%20Copy.html

\section{For further information contact:}

Tel: (86) 1062516305

Email: srsruc@ruc.edu.cn

\section{Embassy of France in South Africa Master Scholarship Programme}

Purpose: The Embassy of France invites students who wish to continue their tertiary education at Master level in France for the academic year September apply for its scholarship programme

Eligibility: 1. Citizenship of South Africa or Lesotho. 2. Bachelor's or Honour's graduate (depending on the academic year to enrol for), completed or to be completed by the time the student would depart for France. 3. Acceptance from three selected French institutions of the candidate's choice. Students should apply for admission to these universities concurrently to the bursary application (admission letters or at least correspondence with the institutions will be required for complete applications). 4. Maximum academic fees (administration and tuition fees combined) financed with a full scholarship: $€ 5,000$. For academic fees higher than $€ 5,000$ co-financing options must be provided (personal savings and/or enterprise sponsorship). 5. Maximum academic fees (administration and tuition fees combined) financed with a full scholarship: $€ 5,000$. For academic fees higher than $€ 5,000$ co-financing options must be provided (personal savings and/or enterprise sponsorship). 6. No knowledge of French language required, depending on the availability of study course in English. Courses relating to the French Language (i.e. translation, interpreting or French language teaching) must follow a different application process

Level of Study: Postgraduate

Type: Scholarship

Value: $€ 5,000$

Length of Study: 1 year

Frequency: Annual

Country of Study: Any country

Closing Date: 15 March

Funding: Foundation

\section{For further information contact:}

Email: audrey.delattre@diplomatie.gouv.fr

\section{Embassy of France in South Africa PhD Grants}

Purpose: The French Embassy scholarship programme offers grants to facilitate in the international academic and scientific mobility of South African and non-South African researchers to French Higher Education institutions. The programme offers the opportunity for doctoral students to integrate into French establishments for specified time periods in order to participate in collaborative research as part of their doctoral research project

Eligibility: 1. Registration for a $\mathrm{PhD}$ at a South African university. 2. A hosting agreement from the French institution. 3. Support letters from your South African supervisor and French co-supervisor, supporting the proposed research project. 4. Applications from all academic disciplines will be considered. 5. No knowledge of French language required, provided the student will be able to conduct research in English

Level of Study: Postgraduate

Type: Scholarship

Value: $€ 1,065$

Frequency: Annual

Country of Study: Any country

Funding: Foundation

\section{For further information contact:}

Tel: (27) 123436563

Email: pretoria@campusfrance.org 


\section{France: French Embassy and Saint-Gobain Master Scholarship}

Purpose: Saint-Gobain and the Embassy of France in South Africa are offering scholarships to South Africans and Basotho graduates to pursue a Master's degree in Business studies or Engineering at public French universities

Level of Study: Postgraduate

Type: Scholarship

Value: $€ 767$ and annual tuition fees $(€ 3,770)$ at public universities

Frequency: Annual

Country of Study: Any country

Application Procedure: Apply online www.southafrica. campusfrance.org/page/campusfrance-south-africa-office

Closing Date: 30 March

Funding: Private

Additional Information: Contacts could be further established with the below link. www.southafrica.campusfrance.org/page/ campusfrance-south-africa-office www.internationalscholar ships.dhet.gov.za/FRANCEFrenchEmbassyandSaint-Gobain MasterScholarship20192020.html

\section{For further information contact:}

Email: pretoria.bourses@campusfrance.org

\section{France: French Embassy Masters and PhD Scholarship Programme}

Purpose: The Embassy of France is offering scholarships to postgraduate South Africans who wish to pursue Master's and Doctoral studies at French higher education institutions

Eligibility: 1. Be a citizen and resident of South Africa. 2. Apply for university admission at three French universities concurrent to the scholarship application (admission letters or at least correspondence with the institutions will be required). Applications to French public universities are recommended since they have French government subsidised fees. 3. French proficiency is not required, provided they are pursuing a study course in English and have the ability to conduct research in English. 4. Courses relating to French language studies (i.e. translation, interpreting or French language teaching) must follow a different application process by contacting Audrey Delattre

Level of Study: Postgraduate

Type: Scholarship

Frequency: Annual

Country of Study: South Africa

Application Procedure: Apply online www.southafrica. campusfrance.org/sites/locaux/files/PhD\%20French\%20Em bassy\%20application\%20form\%202019.pdf

Closing Date: 15 March
Funding: Foundation

Additional Information: www.internationalscholarships. dhet.gov.za/France\%204-\%20Copy.html

\section{For further information contact:}

Email: pretoria@campusfrance.org

\section{France: ISAE-SUPAERO Scholarship Programmes}

Purpose: The ISAE-SUPAERO Institute offers a wide range of science and engineering degree programs with a number of scholarships offered through industry support and the SUPAERO Foundation for pursuing studies towards a Master of Science in Aerospace Engineering degree. These scholarships cover tuition and part of living expenses Eligibility: Applicants who hold a Bachelor's degree or the equivalent in Mechanical Engineering, Mechatronics, Aerospace, Electronics, Electrical Systems, Telecommunications or a French licence in Science and Engineering

Level of Study: Postgraduate

Type: Scholarship

Value: Tuition fees: R10,600, Living expenses: R8,000 to R10,000

Frequency: Annual

Country of Study: South Africa

Application Procedure: Apply online: www.isae-supaero.fr/ en/academics/master-s-degree-msc/admissions/

Funding: Foundation

Additional Information: www.isae-supaero.fr/en/academics/ MSc/financing-144/financing/

\section{For further information contact:}

Tel: $\quad$ (33) 561338027

Email: philippe.galaup@isae-supaero.fr

\section{Hungary: Stipendium Hungaricum for South Africa}

Purpose: The Hungarian Government is offering 100 scholarships to South African students to study at participating public university in Hungary. All courses available for South Africans are taught in English

Eligibility: 1. Be a South African citizen in good health. 2. Have a strong academic record. 3. An interest in studying in Hungary and demonstrated commitment to the development of South Africa. 4. Meet the entry criteria for their selected programme in Hungary. 5. Meet the minimum academic requirement for entry into a similar programme at a South African university

Level of Study: Postgraduate

Type: Grant 
Frequency: Annual

Country of Study: South Africa

Application Procedure: Apply online apply.stipendium hungaricum.hu/

Closing Date: 16 January

Funding: Foundation

Additional Information: www.internationalscholarships. dhet.gov.za/HUNGARY\%20Stipendium $\% 20$ Hungaricum $\%$ 20 for $\% 20$ South $\% 20$ Africa.html

\section{For further information contact:}

Email: HungaryScholarshipApplications2019@dhet. gov.za

\section{India: Export-Import Bank of India BRICS Economic Research Award}

Purpose: The Export-Import Bank of India (EXIM) has instituted the Export-Import Bank of India BRICS Economic Research Award. The award aims to encourage and stimulate advanced research on economics related topics of relevance to the member nations of Brazil, Russia, India, China and South Africa (BRICS). The EXIM Bank of India invites South African research scholars to apply for the Exim, Bank of India BRICS Economic Research Award

Eligibility: Check online www.eximbankindia.in/Assets/pdf/ award/EXIM\%20Bank\%20BRICS\%20Economic\%20Research \%20Award-\%20Guidelines\%20(English)\%2015.04.2019.pdf

Level of Study: Postgraduate

Type: Award

Value: R22 000

Frequency: Annual

Country of Study: South Africa

Application Procedure: Apply online www.eximbankindia. in/awards

Closing Date: 15 April

Funding: Foundation

Additional Information: www.internationalscholarships. dhet.gov.za/INDIAExport-Import\%20Bankof

IndiaBRICSEconomicResearchAward.html

\section{For further information contact:}

Tel:

(91) 2222172701

Email: rag@eximbankindia.in

\section{Indonesia: Kemitraan Negara Berkembang (Developing Countries Partnership) Scholarship}

Purpose: The Kemitraan Negara Berkembang (KNB) Scholarship was first introduced by the Ministry of Education and Culture to embrace higher education globalization by providing financial assistance (scholarship) to the selected Indonesian Universities, to recruit potential international students to acquire Master's degrees in those universities. The KNB Scholarship program has expanded and is now offered to potential students from developing countries to acquire Bachelor's or Master's degrees at the prestigious universities in Indonesia. The Indonesian Government is offering 140 Master's and five Bachelor's degrees scholarships. All programmes are delivered in Bahasa Indonesia

Eligibility: 1. Applicants must not be older than 35 years of age. 2. Applicants must hold a Bachelor degree (Master's degree holder is not eligible to apply). 3. Applicants must have a TOEFL (or other certified English Proficiency) score of 500. 4. Applicants must be between the ages of 18-35 for Undergraduate and Diploma programmes

Level of Study: Postgraduate

Type: Scholarship

Frequency: Annual

Country of Study: South Africa

Application Procedure: Apply online: www.knb.ristekdikti. go.id

Closing Date: 30 April

Funding: Foundation

Additional Information: www.internationalscholarships. dhet.gov.za/INDONESIAKemitraanNegaraBerkembang(De veloping\%20Countries\%20Partnership)Scholarship.html

\section{For further information contact:}

The Information and Socio-Cultural Section, The Embassy of the Republic of Indonesia, 949 Francis Baard Street, Arcardia 0083, South Africa.

Tel: $\quad$ (27) 123423350

Email: info@indonesia-pretoria.org.za

\section{Ireland: Kader Asmal Fellowship Programme}

Purpose: The Embassy of Ireland in South Africa in partnership with the Department of Higher Education and Training and the Canon Collins Trust invites applications for scholarships for one-year Master's degree study in Ireland commencing in September

Eligibility: 1. Be a South African citizen. 2. Have achieved the necessary standard to be accepted onto a postgraduate course in an institute of higher education in Ireland. 3. Be seeking funding for a full-time postgraduate programme in one of the above listed subject areas. 4 . Be able to take up fellowship in the academic year. 5. Not have already applied for a course at an institution in Ireland - if you have already been admitted to a university you are not eligible

Level of Study: Postgraduate 
Type: Fellowships, operating grants

Frequency: Annual

Country of Study: South Africa

Application Procedure: Apply online www.canoncollins. org.uk/apply/scholarship/kader-asmal-fellowship

Closing Date: 31 August

Funding: Private

Additional Information: www.internationalscholarships. dhet.gov.za/IRELANDKaderAsmalFellowshipProgramme 2020.html

\section{For further information contact:}

Email: Rose.Machobane@dfa.ie

\section{Japan: MEXT Scholarships}

Purpose: The Japanese Ministry of Education, Culture, Sports, Science, and Technology (MEXT) offers scholarships to foreign students who wish to study at Japanese universities under the Japanese Government Scholarship Program

Eligibility: see website: www.za.emb-japan.go.jp/itpr_en/ MEXT_Scholarship.html

Level of Study: Postgraduate

Type: Scholarship

Frequency: Annual

Country of Study: South Africa

Application Procedure: Applications must be couriered or be hand delivered and addressed to: Cultural Section of the Embassy of Japan in South Africa: 259 Baines Street, Groenkloof, Pretoria, 0181, South Africa

Closing Date: 8 June

Funding: Foundation

\section{For further information contact:}

Cultural Section of the Embassy of Japan in South Africa, 259 Baines Street, Groenkloof, Pretoria 0181, South Africa.

Email: ryan.keet@pr.mofa.go.jp

\section{Jordan: Talal Abu-Ghazaleh University College for Innovation Scholarship}

Purpose: Talal Abu-Ghazaleh University College for Innovation (TAGUCI) is offering a scholarship for a South African student who wishes to pursue a Master of Business Administration (MBA) degree at TAGUCI. Registration is now open for the semester

Eligibility: 1. Applicants must submit official Bachelor's degree transcripts and certificate, stamped by the Ministry of
Higher Education and Scientific Research in Jordan. 2. English Language Equivalency exam mark of $65 \%$. 3. Minimum of two years of work experience. 4 . Written essay of up to 3,000 words. 5. Candidates must be prepared to fund any costs not covered by the scholarship

Level of Study: Postgraduate

Type: Scholarship

Frequency: Annual

Country of Study: Any country

Application Procedure: Apply online www.taguci.edu.jo/ RegistrationForm.aspx

Closing Date: 28 February

Funding: Foundation

\section{For further information contact:}

Tel: $\quad$ (962) 65100900

Email: info@taguci.edu.jo

\section{Mauritius: Mauritius-Africa Scholarship Scheme}

Purpose: As part of a commitment to promote capacitybuilding at high level across thecontinent, the Government of Mauritius is awarding scholarships to deserving students who are resident citizens of member states of the African Union or of African Commonwealth countries for full-time, on-campus undergraduate and postgraduate programmes tenable in public Higher Education Institutions (HEIs) in Mauritius

Eligibility: The Government of Mauritius is awarding scholarships to deserving students who are resident citizens of member states of the African Union or of African Commonwealth countries as per the following criteria: 1 . For undergraduate programmes, applicants should be above 18 years of age and should not have reached their 26th birthday by the closing date of application. 2. For Master's programmes, applicants should not have reached 35 years and, for $\mathrm{PhD}$ programmes, applicants should not have reached 40 years by the closing date of application. 3. Applicants must have already applied for a full-time on-campus programme (Diploma, Degree, Master's or PhD) at a public Higher Education Institution in Mauritius (listed in Section 8 in the Guidelines for Applicants).

Level of Study: Postgraduate

Type: Scholarship

Value: Tuition fees and course-related costs of up to MUR 100,000; Monthly living allowance to the value of MUR 12,500

Frequency: Annual

Country of Study: South Africa 
Application Procedure: Apply online ministry-education. govmu.org/English/scholarships/Documents/2018/Application \%20Form\%20undergraduate\%20MASS\%2012Jan2018.pdf

Closing Date: 30 April

Funding: Foundation

Additional Information: opportunitydesk.org/2020/01/12/ mauritius-africa-scholarship-scheme-2020/

\section{For further information contact:}

Email: internationalscholarships@dhet.gov.za

\section{New Zealand: Scholarships for International Tertiary Students and Commonwealth Scholarship}

Purpose: The New Zealand Aid Programme offers scholarships to potential applicants from eligible African countries (including South Africa) who are motivated to make a difference at home. Applications are now open for studies

Level of Study: Postgraduate

Type: Scholarship

Frequency: Annual

Country of Study: Any country

Application Procedure: All applications for the New Zealand Scholarship for International Tertiary Students must be submitted online. Please see the below links for more details on the process: All applications for the New Zealand Commonwealth Scholarship must be submitted on this application form. www.internationalscholarships.dhet.gov.za/

Closing Date: 31 March

Funding: Foundation

Additional Information: www.bursariesportal.co.za/bursary/ new-zealand-scholarships-international-tertiary-students-andcommonwealth-scholarship-2021

\section{For further information contact:}

Email: commonwealthscholarship@dhet.gov.za

\section{Romania: Romanian State Scholarships}

Purpose: The Romanian Ministry of Foreign Affairs (MFA) and the Romanian Department of Public, Cultural and Scientific Diplomacy are offering 85 scholarship opportunities to foreign citizens, to study in Romania. This opportunity is open to students who wish to pursue studies in Bachelor's, Master's and PhD. Courses will be taught in Romanian language
Eligibility: 1. Applicants must be in good health and have a strong academic record. 2. Must present study papers issued by accredited / recognized educational institutions. 3. Applicants must not be older than 35 years of age for Bachelor's and Master's studies and 45 years respectively for Doctoral studies, by 31 December of the year in which they are nominated. 4. Candidates must be prepared to fund any costs not covered by the scholarship

Level of Study: Postgraduate

Type: Scholarship

Value: R85

Length of Study: 1 year

Frequency: Annual

Country of Study: South Africa

Application Procedure: Apply online www.mae.ro/en/node/ 10251\#null

Closing Date: 28 February

Funding: Foundation

\section{For further information contact:}

Email: internationalscholarships@dhet.gov.za

\section{Romanian State Scholarships}

Purpose: The Romanian Ministry of Foreign Affairs (MFA) and the Romanian Department of Public, Cultural and Scientific Diplomacy are offering 85 scholarship opportunities to foreign citizens, to study in Romania. This opportunity is open to students who wish to pursue studies in Bachelor's, Master's and $\mathrm{PhD}$.

Eligibility: 1. Applicants must be in good health and have a strong academic record. 2. Must present study papers issued by accredited / recognized educational institutions. 3. Applicants must not be older than 35 years of age for Bachelor's and Master's studies and 45 years respectively for Doctoral studies, by 31 December of the year in which they are nominated. 4. Candidates must be prepared to fund any costs not covered by the scholarship

Level of Study: Postgraduate

Type: Scholarship

Value: R85

Frequency: Annual

Country of Study: South Africa

Closing Date: 28 February

Funding: Foundation

\section{For further information contact:}

Email: internationalscholarships@dhet.gov.za 


\section{Russia: Scholarships for South Africans}

Purpose: The Russian Government offers annual scholarships for South Africans to study at Russian institutions. The scholarship is offered for Bachelor's, Masters and $\mathrm{PhD}$ degrees. Most programmes are taught in the Russian language. Scholarship recipients are required to undertake a preparatory course related to their field of study (including language training) for one year before pursuing their degree studies. Only after passing the examinations of the college preparatory course can they start their degree studies

Eligibility: 1. South African citizens in good health (medical test are required for successful applicants). 2. Have a strong academic record. 3. Demonstrated interest in Russia and commitment to the development of South Africa. 4. Applications in all fields of study except medicine will be considered. 5. Preference will be given to postgraduate applicants, previously disadvantaged applicants and applicants in the following fields

Level of Study: Doctorate

Type: Scholarship

Value: US\$ 400 and US\$ 600 per month for living in Russia

Frequency: Annual

Country of Study: South Africa

Application Procedure: Apply online www.russia.study/en

Closing Date: 20 February

Funding: Foundation

Additional Information: website of the Ministry of Foreign Affairs of the Russian Federation (russianembassyza.mid.ru/).

\section{For further information contact:}

Email: south_africa@rs.gov.ru

\section{Spain: Student and Staff Exchange between South Africa and Spain}

Purpose: Alianza 4 Universidades (A4U) is a consortium of four Spanish public universities. The consortium is funded by the Erasmus+ Programme of the European Union to enable student and staff exchange between universities members of the $\mathrm{A} 4 \mathrm{U}$ and six South African partner universities

Eligibility: 1. Applicants from South African partner universities and A4U universities. South African partner universities include: University of Pretoria, University of the Witwatersrand, Stellenbosch University, University of Cape Town, University of the Western Cape and University of the Free State. 2. A4U Universities participating universities are Universitat Autònoma de Barcelona, Universidad Autònoma de Madrid, Universidad Carlos III de Madrid and Universitat Pompeu Fabra in Barcelona

Level of Study: Postgraduate
Type: Grant

Frequency: Annual

Country of Study: South Africa

Application Procedure: Apply online alliance4universities. eu/en/mobility-scholarships/

Closing Date: December

Funding: Foundation

Additional Information: www.internationalscholarships. dhet.gov.za/SPAIN $\% 20$ Student $\% 20$ and $\% 20$ staff $\% 20$ exchan ge\%20between $\% 20$ South\%20Africa\%20and\%20Spain.html

\section{For further information contact:}

Tel: $\quad$ (34) 935422079

Email: coordinacion@a-4u.eu

\section{Sweden: Swedish Institute Scholarships for South Africa (SISSA)}

Purpose: The Swedish Institute Scholarships for South Africa (SISSA) are being offered for South Africans to undertake Master's degrees at Swedish universities from September

Eligibility: 1. South African citizens in good health with a strong academic record. 2. Must have Bachelor's with Honours or equivalent, and should have performed well in his/her previous studies with minimum $65 \%$ average mark achieved. 3. Have applied for a Master's degree programme at a Swedish university on a full-time basis. 4. Intend to return to South Africa at the end of your studies. 5. Work and leadership experience is not a requirement but will be viewed favourably

Level of Study: Masters Degree

Type: Scholarship

Value: SEK 10,000/month

Frequency: Annual

Country of Study: South Africa

Application Procedure: Apply online si.se/en/apply/scholar ships/swedish-institute-scholarships-for-south-africa/

Closing Date: 19 February

Funding: Foundation

\section{For further information contact:}

Email: Internationalscholarships@dhet.gov.za

\section{Switzerland: Swiss Government Excellence Scholarship for Foreign Students}

Purpose: Through the Swiss Federal Commission for Scholarships for Foreign Students, the Swiss Government Grants foreign researchers, postgraduate scholarships at Swiss higher 
education institutions. The Swiss Government Excellence Scholarship are intended for highly motivated, competitive young researchers who have graduated from university. These scholarships will enable applicants to undertake research work in the fields in which the Swiss universities are particularly active.

Eligibility: 1. South African citizens. 2. Research fellowship applicants must have Master's degree or equivalent achieved and must be born after 31 December 1985. 3. PhD scholarship applicants must have a Master's degree or equivalent achieved and must be born after 31 December 1985. 4. Postdoctoral scholarship applicants must have a $\mathrm{PhD}$ degree achieved after 31 December 2016. 5. Applicants with admission letter from academic host institution. 6. Support letter from supervisor or academic host professor. 7. Research proposal including timeframe.

Level of Study: PhD,Post-doc and Research Fellow

Type: Scholarship

Value: CHF 1,920/month to CHF 3,500/month

Length of Study: 1 year-3 years

Frequency: Annual

Study Establishment: Swiss Confederation

Country of Study: Switzerland

Application Procedure: visit www.sbfi.admin.ch/scholar ships_eng and click on South Africa. Request the application package at pre.vertretung@eda.admin.ch

Closing Date: 15 December

Funding: Foundation

Contributor: Swiss Confederation

\section{For further information contact:}

Tel: (27) 124520660

Email: pre.vertretung@eda.admin.ch

\section{Turkey: Türkiye Scholarships}

Purpose: Türkiye Scholarships is a government-funded, competitive scholarship program, awarded to outstanding students to pursue full-time or short-term program at the top universities in Turkey. Applications will be open to applicants who wish to study at bachelor's, master's and doctoral levels.

Eligibility: 1. Applications for Türkiye Scholarships are open to citizens of all countries. 2. Applicants should not be older than 21 for Bachelor's, 30 for Master's and 35 for Doctoral studies. 3. For Undergraduate degree applications $70 \%$. 4. For Master's and Doctoral degree applications $75 \%$

Level of Study: Postgraduate

Type: Scholarship

Value: Bachelor: TRY 800 per month; Masters: TRY 1,100 per month; PhD TRY 1,600 per month
Length of Study: 1. Undergraduate: 1 year Turkish Language course $+4-6$ years (depending on the normal duration of the program) 2. Master's: 1 year Turkish Language course + 2 years 3 . PhD 1 year Turkish Language course +4 years

Frequency: Annual

Country of Study: South Africa

Application Procedure: Apply online www.turkiyeburslari. gov.tr

Closing Date: 20 February

Funding: Foundation

Contributor: Participating Universities in Turkey

Additional Information: www.turkiyeburslari.gov.tr/en/ announcement/turkiye-scholarships-2020-applications-open

\section{For further information contact:}

Email: info@turkiyeburslari.org

\section{United Arab Emirates: Khalifa University Postgraduate Scholarships}

Purpose: Khalifa University (KU) of Science and Technology is offering postgraduate scholarships to students who wish to pursue postgraduate studies in the field of Engineering Sciences in Abu Dhabi. Through these scholarships, the University aims to highlight the importance of investing in intellectual and human capital as well as its role in enhancing the performance of higher education system

Eligibility: Check website www.ku.ac.ae/admissions/ graduate-admissions/

Level of Study: Masters Degree

Type: Scholarship

Value: R 10,000

Length of Study: 2 Year

Frequency: Annual

Country of Study: South Africa

Application Procedure: Apply online admissions.kustar.ac. ae/pg/Account/Login

Closing Date: 14 February

Funding: Foundation

Additional Information: opportunitiescorners.info/khalifauniversity-scholarship/

\section{For further information contact:}

Email: pgadmission@ku.ac.ae

\section{United States: Fulbright Foreign Student Program}

Purpose: The Fulbright Foreign Student Program enables graduate students, young professionals and artists from 
abroad to study and conduct research in the United States at U.S. universities or other academic institutions.

Eligibility: All Foreign Student Program applications are processed by bi-national Fulbright Commissions/Foundations or U.S. Embassies. Therefore, foreign students must apply through the Fulbright Commission/Foundation or U.S. Embassy in their home countries. Deadline varies per country but is around February to October annually.

Level of Study: Postgraduate

Type: Studentship

Value: living stipend, and health insurance, etc

Frequency: Annual

Country of Study: South Africa

Application Procedure: In order to apply for this scholarship, you could use the following link. apply.iie.org/ffsp2020 No. of awards offered: Approximately 4,000 foreign students receive Fulbright scholarships each year.

Closing Date: February-October

Funding: Private

Additional Information: For further, kindly contact the organisation using the below link. za.usembassy.gov/ education-culture/educational-exchanges/fulbright-flagshipprograms/foreign-student-program-frequently-asked-questions/ www.scholarshiproar.com/fulbright-scholarships-usa/

\section{United States: Harvard South Africa Fellowship Program}

Purpose: The HSAFP was initiated to provide educational enrichment for mid-career individuals in various occupations who have shown considerable skills and leadership in their chosen fields. Applications are invited for the Harvard South Africa Fellowship Program

Eligibility: 1. Fellows must be South African citizens. 2. Usually between 30 and 45 years of age. 3. Must not have just completed or not completed a Bachelor's degree, unless this degree has been pursued concurrently with or subsequent to experience in the workplace. 4. Applicants should determine well in advance whether if awarded a fellowship, they can be granted leave by their employers for Harvard's academic year Level of Study: Postgraduate

Type: Fellowships, operating grants

Frequency: Annual

Country of Study: South Africa

Application Procedure: Apply onlline africa.harvard.edu/ south-africa-fellowship-program

Closing Date: 4 April

Funding: Foundation

Additional Information: www.internationalscholarships. dhet.gov.za/UNITED\%20STATES\%20Harvard\%20South\% 20Africa\%20Fellowship\%20Program\%202020-2021.html

\section{For further information contact:}

Tel: $\quad$ (27) 877010715

Email: AfricaOffice@Harvard.edu

\section{Hilda Martindale Educational Trust}

Royal Holloway, University of London, Egham, Surrey TW20 0EX, United Kingdom.

Tel: $\quad$ (44) 1784276158

Email: hildamartindaletrust@rhul.ac.uk

Contact: Miss Sarah Moffat, Administrator to the Trust

The Hilda Martindale Trust makes one-off awards to British women undertaking training or professional qualifications in areas in which women are underrepresented.

\section{Hilda Martindale Trust Awards}

Purpose: To assist with the costs of training or professional qualifications in areas in which women are under represented

Eligibility: Open to women of the British Isles only. Assistance is not given to short courses, courses abroad, elective studies or access courses. Trust can only offer funding to women pursuing training/qualifications in areas in which women are under represented

Level of Study: Doctorate, Graduate, MBA, Postdoctorate, Postgraduate, Postgraduate (MSc), Predoctorate, Professional development, Undergraduate

Type: Grant

Value: Up to $£ 3,000$

Length of Study: 1 year

Frequency: Annual

Study Establishment: Any establishment approved by the trustees

Country of Study: United Kingdom

Application Procedure: The application form and guidance for applicants are available from the website address below. In addition, requests for an application form can be made by email to Hildamartindaletrust@rhul.ac.uk

No. of awards offered: 55

Closing Date: 5 February

Funding: Private

Contributor: Private trust

No. of awards given last year: 16

No. of applicants last year: 55 
Additional Information: Further information can be obtained via email at hildamartindaletrust@rhul.ac.uk www. royalholloway.ac.uk/studying-here/fees-and-funding/under graduate/scholarships-and-bursaries/scholarships/hilda-mar tindale-trust-awards/

\section{For further information contact:}

College Secretary's Office, RHUL, Egham, Surrey TW20 0EX, United Kingdom.

Email: HildaMartindaleTrust@royalholloway.ac.uk

\section{Hong Kong Baptist University}

AAB703, Level 7, Academic and Administration Building, Baptist University Road Campus, Kowloon Tong, Hong Kong.

Tel: $\quad$ (852) 34112188

Contact: Hong Kong Baptist University

Hong Kong Baptist University (HKBU) is a publicly funded tertiary institution with a Christian education heritage.

\section{Fully Funded Master Scholarship at Hong Kong Baptist University}

Purpose: The aim of the scholarship is to encourage the study of International Journalism

Eligibility: Vietnam, Philippines, India and Indonesia. Applicants must have a valid minimum TOEFL iBT 79 or IELTS 6.5

Value: HKBU Fully Funded International Postgraduate Scholarship

Country of Study: Any country

Application Procedure: The mode of applying is online Closing Date: March

Additional Information: For more details please see the website scholarship-positions.com/fully-funded-master-scho larship-hong-kong-baptist-university/2018/01/04/ worldscho larshipforum.com/hkbu-scholarship/

\section{For further information contact:}

Email: busd-external@hkbu.edu.hk

\section{Horowitz Foundation for Social Policy}

106 Somerset St, 7th Floor, New Brunswick, NJ 08901, United States of America.

Tel: $\quad$ (1) 7324452280

Website: www.horowitz-foundation.org

The Horowitz Foundation for Social Policy was established to support the advancement of research and understanding in the social sciences including: psychology, anthropology, sociology, economics, and political science. The Foundation assists individual scholars at the early stages of their career who require small grants to complete their dissertations.

\section{Irving Louis Horowitz Award}

Purpose: Awarded to the project that best represents the goals of the Horowitz Foundation in a specific award year Eligibility: Open to nationals of any country. Candidates may solicit support for final work on a dissertation, including travel funds

Level of Study: Doctorate

Type: Award

Value: US $\$ 12,500$ (US\$10,000 initially and an additional US $\$ 2,500$ upon receipt of a final report on a copy of the research)

Length of Study: 1 year

Frequency: Annual

Country of Study: Any country

Application Procedure: Applicants are not required to be United States citizens or United States residents. Candidates may propose new projects, and they may also solicit support for research in progress, including final work on a dissertation, supplementing research in progress, or travel funds. Awards are only open to aspiring PhDs at the dissertation level whose project has received approval from their appropriate department head/university. Grants are normally made for 1 year on a non-renewable basis. Awards will be made to individuals, not institutions, and if processed through an institution, a waiver for overhead is requested. A copy of the product of the research is expected no later than 1 year after completion. Upon receipt an additional US\$2,500 will be paid. Recipients are expected to acknowledge assistance provided by the Foundation in any publication resulting from their research. Awards are publicized in appropriate professional media and on the Foundation website No. of awards offered: 300

Closing Date: 31 January 
Funding: Private

No. of awards given last year: 15

No. of applicants last year: 300

Additional Information: The cover sheet in the application is most important, as it is the basis for the initial screening of prospects. www.horowitz-foundation.org/grant-info

\section{For further information contact:}

Email: wagner.events@nyu.edu

\section{Refugee Study Awards}

Purpose: The Refugee Study Awards are for women who are studying for a New Zealand tertiary qualification, and who have not been through the New Zealand school system. The awards are a one off grant to help with study and/or living expenses

Eligibility: To apply for the Refugee Study Awards you must meet all the following eligibility criteria: The applicant is a woman, who: 1. Is enrolled in a NZ approved tertiary qualification. 2. Is studying at diploma or degree level (NZQA level 5 or above). 3. Is a New Zealand citizen or holds a resident class visa, and lives in New Zealand. 4. Provides evidence of having arrived in New Zealand as a refugee - ID card or NZ Immigration Service refugee travel document. Has not previously received a NHWTHK Award

Level of Study: Graduate

Type: Award

Value: NZ $\$ 3,000$

Frequency: Annual

Country of Study: Any country

Application Procedure: Please check the following website link for further details. www.newhorizonsforwomen.org.nz/ awards/manawatu-charitable-trust-refugee/

No. of awards offered: 2

Closing Date: 15 April

Funding: Private

\section{For further information contact:}

New Horizons for Women Trust, PO Box 12498, Wellington, NZL 6144, New Zealand.

Email: enquiries@newhorizonsforwomen.org.nz

\section{The Horowitz Foundation for Social Policy}

Eligibility: Awards are open only to $\mathrm{PhD}$ candidates whose project has received approval from their appropriate department head/university. Preference is given to projects that address contemporary issues in the social sciences and issues of policy relevance. Applicants are not required to be citizens or residents of the United States. Awards are based solely on merit, not to ensure a representative base of recipients or disciplines

Level of Study: Doctorate

Type: Grants and fellowships

Value: NZ\$7,500 - NZ $\$ 5,000$ initially and an additional NZ\$2,500 upon completion of the project. Criteria for completion include approval of the dissertation, acceptance of an article based on the research by a peer-reviewed journal, or an invitation to write a book chapter based on the research. Additional awards are given in certain suspect areas. The best overall project (as determined by the trustees) receives an additional NZ\$5,000

Frequency: Annual

Country of Study: Any country

Application Procedure: Applications must be submitted through our online system which can be found on our website www.horowitz-foundation.org

No. of awards offered: 700

Closing Date: 1 December

Funding: Private

No. of awards given last year: 20

No. of applicants last year: 700

Additional Information: All submitted applications, letters, and documents must be in English. Applications are open 1 July through 1 December. Applicants are encouraged to apply as early as possible. Submitted materials become the property of the Foundation and will not be returned. Applicants should not send originals or other materials that cannot be replaced sociology.fas.harvard.edu/horowitz-foundationsocial-policy-grant

\section{For further information contact:}

Email: horowitz-foundation.org

\section{Hosei University}

17-1 Fujimi 2 chome, Chiyoda-ku, Tokyo, JP 102, Japan.

Tel: $\quad$ (81) 332649564

Email: ic@I.hosei.ac.jp

Website: www.hosei.ac.jp/ic

Contact: Ms Keiko Takahata, Executive Assistant

\section{Master of Business Administration Programme}

Application Procedure: Applicants must complete an application form supplying official transcripts, passport sized photograph, curriculum vitae and a statement of financial support Closing Date: 30 November 


\section{For further information contact:}

Business Adminstration, 2-17-1 Fujimi, Tokyo 102, Japan.

Tel: $\quad$ (81) 332649315

Fax: (81) 332389873

Email: ic@fujimi.hosei.ac.jp

\section{Hospitality Maine}

Hospitality Maine, 45, Melville St., Augusta, ME, 04330, United States of America.

Tel: $\quad$ (1) 2076232178

Website: www.hospitalitymaine.com

\section{Hospitality Maine Scholarships}

Purpose: This scholarship is available for Maine students who plan to pursue a career in culinary arts or hospitality. It is open to graduating high school students, as well as those already enrolled in a culinary or hospitality program.

Eligibility: 1. Must be a resident of Maine. 2. Must be a United States citizen or permanent resident. 3. Must be a high school senior or older to apply for this undergraduate award. 4. Must be planning to pursue a culinary arts or hospitality-oriented program.

Level of Study: Graduate

Type: Scholarship

Value: US\$1,000 - US\$2,000

Frequency: Annual

Country of Study: United States of America

Application Procedure: Applications are available on the Hospitality Maine website under Resources.

No. of awards offered: Multiple

Funding: Foundation

For further information contact:

Email: becky@hospitalitymaine.com

Website: www.hospitalitymaine.com

\section{Howard Hughes Medical Institute (HHMI)}

4000 Jones Bridge Road, Chevy Chase, MD 20815-6789, United States of America.

Tel: $\quad$ (1) 3012158500

Website: www.hhmi.org
HHMI is a science philanthropy whose mission is to advance biomedical research and science education for the benefit of humanity. We empower exceptional scientists and students to pursue fundamental questions about living systems.

\section{Howard Hughes Medical Institute Gilliam Fellowships for Advanced Study}

Purpose: The goal of the Gilliam Fellowships for Advanced Study program is to ensure the development of a diverse and highly trained workforce is available to assume leadership roles in science, including college and university faculty, who have the responsibility to teach the next generation of scientists

Eligibility: Adviser-student pairs from eligible disciplines must be nominated by the HHMI-designated institutional representative. Prospective fellows must be i) U.S. citizens, U.S. permanent residents, undocumented childhood arrivals, or undocumented individuals who have been granted temporary permission to stay in the US (DACA), and ii) be from populations excluded from science, or alumni of the HHMI EXROP and iii) be at the appropriate stage of their $\mathrm{PhD}$ training.

Type: Fellowship

Value: US\$50,000 per year

Length of Study: Up to 3 years of their dissertation research, typically in years 3,4 , and 5 of their PhD studies

Frequency: Annual

Country of Study: United States of America

Closing Date: 10 December

Additional Information: www.hhmi.org/science-education/ programs/gilliam-fellowships-advanced-study

\section{For further information contact:}

Email: Gilliam@hhmi.org

\section{Postdoctoral Research Fellowships for Physicians}

Purpose: To help increase the supply of well-trained physician-scientists, through fellowships for three years of training in fundamental research (basic biological processes or disease mechanisms)

Eligibility: Applicants must have gained their first degree within the last ten years, and must have had two years of postgraduate clinical training, and no more than two years of postdoctoral training in fundamental research

Level of Study: Postdoctorate

Type: Fellowship

Value: US\$69,000-86,500 per year

Length of Study: 3 years

Frequency: Annual 
Study Establishment: Academic or non-profit research institution

Country of Study: United States of America

Application Procedure: Application forms and instructions should be obtained from the address shown. Panels of scientists review applications, and the Institute makes the final selection No. of awards offered: 255

Closing Date: December

No. of awards given last year: 30

No. of applicants last year: 255

Additional Information: Fellows must engage in full-time research. During the fellowship term, they may not be enrolled in a graduate degree program, nor hold a faculty appointment. The applicant is responsible for selecting a research mentor and making arrangements to work in that person's laboratory. www.hhmi.org/programs/gilliam-fellow ships-for-advanced-study

\section{For further information contact:}

4000 Jones Bridge Road, Chevy Chase, MD 20815, United States of America.

Tel: $\quad$ (1) 3012158889

Fax: (1) 3012158888

Email: fellows@hq.hhmi.org

\section{Humane Research Trust}

The Humane Research Trust, Brook House, 29 Bramhall Lane South, Bramhall, Stockport, Greater Manchester SK7 2DN, United Kingdom.

\section{Tel: $\quad$ (44) 1614398041}

Website: www.humaneresearch.org.uk

Contact: Jane McAllister, Trust Administrator

The Humane Research Trust is a national charity, which funds a range of unique medical research programmes on human illness at hospitals and universities around the country. In keeping with the philosophy of the Trust, none of the research involves animals and much of it seeks to establish and develop pioneering techniques that will replace animal intensive experiments.

\section{The Humane Research Trust Grant}

Subjects: Humane Research

Purpose: To encourage scientific programmes where the use of animals is replaced by other methods
Eligibility: Open to established scientific workers engaged in productive research. Nationals of any country are considered but for the sake of overseeing, projects should be undertaken in a UK establishment.

Level of Study: Unrestricted

Type: Grant

Value: Full funding of a project

Length of Study: Varies

Frequency: Dependent on funds available

Country of Study: United Kingdom

Application Procedure: Applicants must complete an application form, available on the website www.humaneresearch. org.uk Please ensure you email all of the required documents, i.e. one fully complete application to info@humaneresearch. org.uk and post 10 hard copies to The Humane Research Trust.

No. of awards offered: Varies

Closing Date: 30 April

Funding: Private

Additional Information: The Humane Research Trust is a registered charity and donations are encouraged. www. hhmi.org/programs/gilliam-fellowships-for-advanced-study

\section{For further information contact:}

The Humane Research Trust, 29 Bramhall Lane South, Bramhall, Stockport SK7 2DN, United Kingdom.

Email: info@humaneresearch.org.uk

\section{Humboldt University of Berlin}

Office for Promotion of Young Researchers in the Excellence Initiative, Berlin, D-10099, Germany.

Tel: (49) 3020931795

Contact: Humboldt Graduate School

\section{Humboldt Postdoc Scholarships}

Purpose: To support young researchers in taking the next step in their academic career after acquiring their PhD.

Eligibility: Eligible to excellent researchers who either already hold a PhD from Humboldt-Universität or are about to complete their doctorate at Humboldt-Universität $\mathrm{zu}$ Berlin and who wish to conduct a postdoctoral research project. Half of the scholarships will be awarded to women

Type: Scholarship 
Value: $€ 1,500$ per month is awarded for up to 6 months, Application Procedure: Applications can be received only additional family allowances are available, travel expenses may be covered. In exceptional cases, funding can be extended for up to an additional 6 months

Study Establishment: Humboldt-Universität

Country of Study: Germany

via an online application portal

For further information contact:

Email: hgs-grants@hu-berlin.de 